\title{
MAGALHÃES, Nara M. E. O povo sabe votar: uma visão antropológica. Petrópolis: Vozes, 1998. $140 \mathrm{p}$.
}

\section{Francisco Pereira Neto* \\ Universidade Federal do Rio Grande do Sul - Brasil}

O livro de Nara Magalhães segue o caminho de iniciativas enriquecedoras no campo das ciências sociais, as quais procuram tensionar a especialização temática apresentada nas diferentes áreas deste campo de conhecimento. Sem deixar de reconhecer as vantagens que a especialização traz ao conhecimento científico em termos do aprimoramento do instrumental analítico, é importante ressaltar que a natureza do objeto de estudo das ciências sociais impõe uma vigilância constante nas fronteiras estabelecidas nesse processo. Por ser uma ciência profundamente dependente das transformações próprias às dinâmicas históricas, o risco de "encastelamento" em áreas estanques normalmente representa um prejuízo para a sua capacidade de investigação da realidade.

O trabalho de Nara Magalhães lança um olhar antropológico para o tema da política, aventurando-se por questões que são caras aos cientistas políticos, por exemplo, como e por que determinado grupo social vota. Evidentemente que o tema da política não é novidade para a antropologia. A antropologia política já foi consagrada como campo de estudo há algum tempo, especialmente através de antropólogos ingleses (Evans-Pritchard, Fortes, Gluckman, Leach) que estudaram política na África e no Oriente a partir de meados do século XX. A novidade das novas abordagens, nas quais o trabalho de Nara se insere, é que agora a política que está sendo analisada não se restringe àquela das sociedades tribais, mas à política institucionalizada nas sociedades complexas. Este olhar para "dentro" de nossas crenças, concepções e práticas políticas parece uma tendência na antropologia brasileira, como mostra o interesse em trabalhos como o organizado por Palmeira e Goldman, Antropologia, voto e representações políticas.

\footnotetext{
* Doutorando em Antropologia Social.
} 
A contribuição que uma abordagem antropológica pode trazer ao estudo da política em nossas sociedades passa necessariamente pela preferência por métodos qualitativos de pesquisa, característica da disciplina. Essa situação fica clara no esforço da autora em levar adiante uma das operações mais importantes do método etnográfico, ou seja, a de estranhar o familiar. Ao explicitar o seu lugar no universo da pesquisa, Nara mostra a centralidade que a política tem na conformação de seus valores, de sua visão de realidade. Como militante de um partido político, o Partido dos Trabalhadores, através do qual compartilha uma perspectiva que coloca a política num lugar central em termos de ordenação da sociedade e da cultura, a autora demonstra seu desconforto com as dificuldades de trânsito de sua mensagem política por grupos sociais menos favorecidos do ponto de vista sócio-econômico.

Ao que parece os problemas postos pelas indagações de Nara Magalhães são o cerne das questões propostas por pensamentos que pretendem a transformação social e que vêem o espaço político como o locus privilegiado para que tal processo ocorra. Evidentemente que tal pressuposição está alicerçada pela visão moderna que coloca o campo político como o espaço do exercício do poder e, conseqüentemente, da possibilidade de mudança em sociedades em que o Estado estabelece seus princípios de organização.

O que fazer então com grupos representativos destas sociedades que se dizem não-políticos, propondo um discurso que estabelece a política como negatividade. Se para lidarmos com essa questão nos posicionamos no quadro lógico do sistema que pretende se estabelecer como representativo da visão moderna de sociedade, destaca-se imediatamente o problema do não conhecimento de uma realidade que se impõe. Ou seja, as discussões se situam no problema da não-consciência de alguns grupos sociais que, em função de "deficiências" causadas por uma posição inferior na hierarquia social, estariam distantes das condições necessárias para gerir suas vidas de uma forma adequada às necessidades da vida moderna.

A autora rejeita este viés analítico através da crítica à visão marxista de ideologia que define como não-consciência, como falseamento da realidade, os discursos e práticas que destoam do que poderíamos entender como o desenvolvimento de um modelo moderno de consciência política para a sociedade. Como alternativa para essa concepção Magalhães sustenta a expansão do campo de expressão da política, retirando dessa visão moderna de política o privilégio da definição exclusiva do que poderíamos chamar de "boa" 
política. Propõe o acatamento da política como cultura, valorizando para a sua definição a experiência cotidiana dos grupos sociais: "Tomo a política como integrante da cultura, passível também de reelaborações simbólicas” (p. 28).

Assim, ao não compactuar com a versão da "falta" ou "ausência" de consciência política por parte daqueles que proclamam a condição de contrários a política e aos políticos, a autora opta por explorar a possibilidade de uma visão política alternativa respaldada num espaço cultural consagrado nos debates da antropologia brasileira, ou seja, aquele desvendado pelos estudos sobre os grupos populares brasileiros.

De início a autora assume a predisposição de buscar o popular "autêntico" nas práticas e representações de um grupo social imaginado como autônomo, que desenvolve-se culturalmente à margem das instituições dominantes. Porém, no decorrer do trabalho mostra-se ciente do perigo de incorrer nas substancializações próprias a alguns trabalhos de tradição culturalista e trata de ressaltar o aspecto relacional das discussões que envolvem o campo popular e a política. Esse movimento é expresso por opções teóricas que levam a perceber a relação entre o político e o cultural através de conceitos como o de hegemonia proposto por Gramsci, onde a relação de poder entre os diferentes grupos sociais se configuram numa negociação que pressupõe consentimento; ou o de imaginário coletivo, que propõe a possibilidade de entendimento comum através das representações que compõem as idéias de política nas sociedades, configurando muito mais um entendimento em linhas gerais do que uma concepção monolítica da política. Assim, na definição do grupo estudado, a autora descarta a utilização do conceito de classe popular, que forçaria a idéia de uma consciência política autônoma, optando por um conceito mais "aberto" como o de grupos populares.

Essas questões estão presentes na análise de três períodos eleitorais distintos em Porto Alegre: a eleição para prefeito em 1985, as eleições presidenciais de 1989 e as eleições para prefeito em 1992. Trata-se, portanto, de fixar a reflexão sobre representação política dos grupos populares baseada nos momentos especiais constituídos pelos períodos eleitorais.

$\mathrm{Na}$ análise fica clara a preocupação da autora em demonstrar que no discurso dos pesquisados a política é vista como algo distante, pouco significativo. Freqüentemente o texto passa a idéia de um descolamento entre os interesses dos grupos populares e as propostas políticas veiculadas através dos candidatos e seus partidos. Por outro lado, essa discrepância de interesses 
não significa uma postura passiva dessa população na participação dos pleitos eleitorais. Nara mostra a presença de uma série de filtros, de critérios, acionados no momento da escolha dos candidatos.

A base para esta escolha não está fundada em nenhum modelo de desenvolvimento que privilegie a idéia de uma consciência de classe esclarecedora de uma posição definida no jogo das relações de poder e das opções políticas, mas muito mais nos significados produzidos pela experiência cotidiana dos grupos sociais pesquisados. É nesse fluxo da vivência cotidiana de formatação pouco precisa, onde se interpenetram vários elementos que constituem os significados da realidade, que a autora vai perceber a possibilidade de definição de uma lógica que balize a atuação política desses grupos. Sem vislumbrar nesse espaço do cotidiano o locus de expressão de uma posição política clara, até porque a posição mais efetiva nesse campo é justamente a negativização do político, a autora propõe-se a balizar o discurso dos partidos políticos em campanha com as representações sobre política dos grupos populares. Nessa tensão entre emissão e recepção do discurso político, ela pretende perceber os caminhos pelos quais passa a reelaboração do discurso político por parte do grupo pesquisado, tentando apreender a lógica que sustenta o posicionamento político dos mesmos. E nesse processo que a autora identifica, por exemplo, a ênfase do voto na pessoa do candidato, em contraste com o ideal moderno de opção por programas políticos; ou mesmo a importância de valores religiosos na definição dos candidatos mais adequados. Sem dúvida essas características mostram um esforço dos eleitores pesquisados em produzir uma proximidade com o universo da política, visto e construído distante do cotidiano desses grupos sociais.

As questões colocadas no trabalho de Nara Magalhães contribuam para pensar a natureza e os limites do universo da política no Brasil, uma vez que muitos elementos que fundamentam uma postura contrária à política de um modo geral parecem superar os limites das representações dos grupos populares sobre o tema, e instaurarem-se em outros segmentos importantes da sociedade brasileira. 